\title{
Solution Proposal For Supplier Selection Problem: An Application In Agricultural Machinery Sector With Global Criterion Method
}

\author{
Nurullah UMARUSMAN ${ }^{1} \quad$ Turgut HACIVELİĞGLLARI ${ }^{2}$
}

\begin{abstract}
The pressure arising from the competition among businesses has placed supply chain and supply chain management as a significant topics in terms of their strategy building and success. Due to one or many conflicting criteria in choosing suppliers, it is a great problem to select the most appropriate supplier or suppliers. This study deals with the supplier selection problem of a business in agricultural machinery sector in Aksaray, Turkey, from the standpoint of Multiple Objective Decision Making Process. The problem of the business is first defined according to Multiobjective Linear Programming, and the compromise solution of the problem was carried out based on Global Criterion Method.
\end{abstract}

Keywords: Agricultural Machinery, Global Criterion Method, Supplier Selection.

JEL Classification Codes: C44, C61.

\section{Tedarikçi Seçim Problemi İçin Çözüm Önerisi: Global Kriter Yöntem Ve Tarım Makineleri Sektöründe BirUygulama}

$\ddot{O} z$

İşletmelerarasırekabetbaskısıtedarikzinciriveyönetiminiişletmelerinstratejikurmaveişbaş arılarındadikkatealdıklarıönemlikonulardanbirihalinegetirmiştir.Tedarikçi seçiminde birbiriyle çatışan birden fazla kriter sebebiyle, işletmelerin istekleri doğrultusunda en uygun tedarikçi veya tedarikçileri belirlemesi önemli bir problemdir. Bu çalışmada Türkiye'de Aksaray şehrindeTarım Makineleri sektöründe faaliyet gösteren bir işletmeninin tedarikçi seçimi problem Çok Amaçlı Karar Verme süreci açısından ele alınmıştır. İşletmenin problemi ilk olarak Çok Amaçlı Doğrusal programlama modelinde düzenlenmiş ve problemin uzlaşık çözümü Global Kriter Yönteme göre yapılmıştır.

AnahtarKelimeler: TarımMakineleri, Global KriterYöntem, TedarikçiSeçimi.

JEL SinıflandırmaKodlart: C44, C61.

1 Dr. Öğr. Üyesi, Aksaray Üniversitesi, İktisadi ve İdari Bilimler Fakültesi, İşletme Bölümü, nurullah.umarusman@aksaray.edu.tr

2 İşletme Doktora Programı Öğrencisi, Aksaray Üniversitesi, Sosyal Bilimler Enstitüsü, turgut@gmx.ch 


\section{N.UMARUSMAN - T.HACIVELİOĞULLARI}

1. INTRODUCTION

The primary cost of a product is made up of the cost of its raw materials and components. As many businesses spend a significant amount of their income through their purchasing departments, the process of selecting suppliers has gained more importance. Supplier selection means choosing the suppliers with the greatest potential to provide for a company's needs within a consistent and acceptable cost(Kılınçcı and Önal, 2011). Supplier selection includes both qualitative and quantitative factors and is vital in supply chain management. The criteria to determine suppliers during the supplier selection process and the methods to facilitate supplier selection are important. According to Sawik (2010) supplier selection is a decision problem inheriting both qualitative and quantitative factors, and one disadvantage of mathematical programming methods is that they cannot explain the qualitative factors which could influence supplier performance. Some researchers propose hybrid approaches that combine different methods to account for qualitative and quantitative factors.

Supplier selection can also be termed as one of the most significant activities of purchasing departments in businesses. As purchasing decisions depend on price, quality, and delivery properties, businesses need to develop new strategies constantly (Amid et al.,2006). Supplier Selection Process offers a structure that guides and directs companies. Selecting the right supplier is like choosing the right business partner; if you make the right decision, you form a potentially permanent relation. Selecting the wrong supplier can damage or ruin a possibly good project(Power et al, 2006: 33).Modern supply management means building a long term cooperation using a few reliable supplier. Therefore, choosing the right supplier would depend on various factors that include both qualitative and quantitative subjects rather than going through price lists (Ho et al., 2010). It is because 
the members of a supply chain are the critical determinants of a supply chain formation. Therefore, partner selection is one of the important steps in forming a supply chain (Chen, 2005). As technological developments progress and their complexity increases, it gets more dynamic and complex to analyse and solve supplier selection (Ding et al., 2003). Selecting the right suppliers is the key in supply process and a good opportunity to cut down costs. On the other hand, selecting the wrong supplier can lead to operational and financial problems (Weber, 1991). Supplier Selection Criteria differ based on the characteristic structures of companies. In addition to their needs, each and every company may have different principles and policies. Companies determine their own Supplier Selection Criteria based on their methods and work flows. Dickson (1966: 11) was the first to define 23 criteria to be used in supplier selection. Afterwards, Dempsey (1978), Roa and Kiser (1980) and Bache et al. (1987) defined various numbers of criteria.

\section{LITERATURE ANALYSIS}

Supplier Selection problems can be solved with different decision making methods. A literature summary is provided here about the linear mathematical methods used in supplier selection. Ghodsypour and O’Brien (1996) proposed an integration of Analytic Hierarchy Process and Linear Programming which includes tangible and abstract factors for the best Supplier Selection. Kumar et al. (2004) applied Fuzzy Goal Programming approach to solve multiobjective supplier selection problems with some fuzzy parameters. Amid et al. (2006) defined asymmetrical fuzzy decision making technique with an example for the first time to enable decision makers to attribute different weights to various criteria. Mizrak-Özfirat and Öğ̈̈t (2008) utilized AHP and Goal Programming together to solve the supplier selection problem of a textile company. Lee et al. (2009) developed 


\section{N.UMARUSMAN - T.HACIVELIOĞULLARI}

Fuzzy Goal Programming model to see the Multiple Factor Analysis which includes cost, profit, and supplier number by incorporating different expert analyses in supplier selection. Wu et al. (2010) proposed Fuzzy Multiobjective Programming model to assist decisions in supplier selection problems by accounting for risk factors. The proposed model creates a supply chain model which is made of three levels using qualitative and quantitative data. Amid et al. (2011) developed a Weighted Max-min Fuzzy Model to control the uncertainty of different weight criteria and input in supplier selection and used AHP model to weight criteria.

Shaw et al. (2012) presented an integrated approach of Fuzzy AHP and Fuzzy Multiobjective Linear Programming to select the appropriate supplier in a supply chain for carbon emission problem. Arikan (2013) proposed Fuzzy Mathematical Model as a new approach to meet the fuzzy requests of decision makers. Shirkouhi et al. (2013) created an interactive Two-phase Fuzzy Multiobjective Linear Programming model to solve fuzzy multiobjective supplier selection and order allocation problems with piecewise linear membership functions. Choudhary and Shankar (2014) applied Multiobjective Integer Linear Programming for supplier selection and shipper selection problem with inventory lot size. Aghai et al. (2014) summarized Fuzzy Multiobjective Programming model by considering qualitative and quantitative risk factors in supplier selection. Jadidi et al. (2015) developed a supplier selection problem using "Multi-Choice Goal Programming” which aims to minimize price, reject, and delivery period presuming the demand and supplier capacity. Govindan et al. (2017) formulized a Fuzzy Multiobjective Model for an optimal secetion of supplier and shipper in an eco-efficient closed-circuit Supply Chain Network. Lee (2017) proposed a fuzzy multiobjective programming approach to account for concurrent consideration of information diversion 

Cilt:33, Sayl:1, Yll:2018, ss. 353-368

and relative importance of goals in determining the allocation of the order amount and emergency capacity to each supplier.

\section{MULTIOBJECTIVE SUPPLIER SELECTION}

The most evident difference between the classical optimization problems and Multiple Objective Decision Making problems stems from the number of objective functions. The fundamental aim of classical optimization problems is to define the variables which provide the best solution. Therefore, the objective function has only one value. As there are more than one objective function in Multiple Objective Decision Making Problems, no objective function has a single value (Lai and Hwang, 1994: 28). In terms of Multi Criteria Decision Making, supplier selection can be regarded as a special case of Multiobjective Linear Programming (Amid et al., 2011). Mathematical programming for supplier selection was first utilized by Gaballa (1974) by using Integer Programming. The multiobjective mathematical model for supplier selection is defined as follows (Weber and Current, 1993).

$$
\begin{aligned}
& \operatorname{Min} \mathrm{W}_{1}=\sum_{\mathrm{i}=1}^{\mathrm{n}} \mathrm{P}_{\mathrm{i}}(\mathrm{x}) \\
& \operatorname{Min} \mathrm{W}_{2}=\sum_{\mathrm{i}=1}^{\mathrm{n}} \mathrm{F}_{\mathrm{i}}(\mathrm{x}) \\
& \operatorname{Max} \mathrm{Z}_{1}=\sum_{\mathrm{i}=1}^{\mathrm{n}} \mathrm{S}_{\mathrm{i}}(\mathrm{x})
\end{aligned}
$$

Subject to 


$$
\begin{aligned}
& \quad \begin{array}{l}
\text { N.UMARUSMAN }- \text { T.HACIVELIOĞULLARI } \\
\sum_{\mathrm{i}=1}^{\mathrm{n}} \mathrm{x}_{\mathrm{i}} \geq \mathrm{D} \\
\mathrm{x}_{\mathrm{i}} \leq \mathrm{C}_{\mathrm{i}} \\
\mathrm{x} \geq 0 \text { and integer }
\end{array} \\
& \mathrm{x}_{\mathrm{i}} \text { : Order quantity given to the supplier } i, \\
& \text { D: Aggregate demand of the item over a fixed planning period, } \\
& n: \text { Number of suppliers competing for selection, } \\
& P_{i} \text { :Price of a unit item of the ordered quantity } \mathrm{x}_{\mathrm{i}} \text { to the supplier } i, \\
& F_{i} \text { :Rejected percentage, } \\
& S_{i} \text { :After-sale Services percentage. }
\end{aligned}
$$

Positive ideal solution and negative ideal solution values should be determined for each objective function in (1). Positive ideal solutions are defined as $\mathrm{I}^{*}=\left\{\mathrm{Z}_{1}^{*}, \mathrm{Z}_{2}^{*}, \ldots \mathrm{Z}_{\mathrm{n}}^{*} ; \mathrm{W}_{1}^{*} \mathrm{~W}_{2}^{*}, \ldots, \mathrm{W}_{\mathrm{n}}^{*}\right\}$.

The minimization of the distance between the acquired solutions and the ideal solutions, namely the proximity to the positive ideal solutions, are conducted with different methods (Zeleny, 1982:281). The solution can be identified with Compromise Programming, Goal Programming, Global Criteria Method, and Fuzzy Logic models based on the ideal solutions (Zimmermann, 1978). Global Criteria Method was used in this study as it investigates results based on positive ideal solution values which do not utilize preference information.

\subsection{Global Criteria Method}

Global Criteria Method (Hwang and Masud, 1979:21) is a method in the classification of Multi Criteria Decision Making which does not require any preference information from the decision maker. This method includes a 
single goal function that investigates the minimization of the total deviation arising from the ratio of each goal function's deviations from its own ideal value to the ideal value.

$$
\left(\sum_{\mathrm{k}=1}^{\mathrm{l}}\left[\frac{\mathrm{Z}_{\mathrm{k}}\left(\mathrm{x}^{*}\right)-\mathrm{Z}_{\mathrm{k}}(\mathrm{x})}{\mathrm{Z}_{\mathrm{k}}\left(\mathrm{x}^{*}\right)}\right]^{\mathrm{p}}\right)^{1 / \mathrm{p}}
$$

Each objective function in the global goal function is expressed as a ratio. Nondimensionalization is important as objective functions have different dimensions (units). The best solution for the problem varies on the selected p- value. While these deviations are weighted proportional to the largest deviation with the greatest weight based on $\mathrm{p}=2$ proposed by Salukvadze (1974), the same significance is given to all deviations based on $\mathrm{p}=1$ proposed by Boychuk and Ovchinnikov (1973). In case on $\mathrm{p}>2$, the weight of deviations will be greater. Umarusman and Türkmen (2013) generalized the objective function of Global Criteria Method for problems with maximization and minimization directions. First, the minimization directed goals are formed by

$$
\left(\sum_{S=1}^{\mathrm{r}}\left[\frac{\mathrm{W}_{\mathrm{s}}(\mathrm{x})-\mathrm{W}_{\mathrm{s}}\left(\mathrm{x}^{*}\right)}{\mathrm{W}_{\mathrm{s}}\left(\mathrm{x}^{*}\right)}\right]^{\mathrm{p}}\right)^{1 / \mathrm{p}}
$$

organizing. Here, p $(1 \leq \mathrm{p}<\infty)$ is a distance parameter.Afterwards, Global Criteria Method is set as seen below according to equations (2) and (3).

$$
\text { Min } G=\sum_{\mathrm{k}=1}^{\mathrm{l}}\left[\frac{\mathrm{Z}_{\mathrm{k}}\left(\mathrm{x}^{*}\right)-\mathrm{Z}_{\mathrm{k}}(\mathrm{x})}{\mathrm{Z}_{\mathrm{k}}\left(\mathrm{x}^{*}\right)}\right]^{\mathrm{p}}+\sum_{\mathrm{s}=1}^{\mathrm{r}}\left[\frac{\mathrm{W}_{\mathrm{s}}(\mathrm{x})-\mathrm{W}_{\mathrm{s}}\left(\mathrm{x}^{*}\right)}{\mathrm{W}_{\mathrm{s}}\left(\mathrm{x}^{*}\right)}\right]^{\mathrm{p}}
$$

Subject to

$$
\begin{aligned}
A x & \leq b \\
x & \geq 0,
\end{aligned}
$$




\section{N.UMARUSMAN - T.HACIVELIOĞULLARI}

Here, $\quad \mathrm{Z}_{\mathrm{k}}=\left(\mathrm{Z}_{1}, \ldots, \mathrm{Z}_{\mathrm{l}}\right) \in \mathbb{R}^{\mathrm{l}}, \quad \mathrm{W}_{\mathrm{s}}=\left(\mathrm{W}_{1}, \ldots, \mathrm{W}_{\mathrm{r}}\right) \in \mathbb{R}^{\mathrm{r}} \quad$ and $\quad \mathrm{V}=$ $\left(V_{1}, \ldots, ., V_{n}\right)=p A \in \mathbb{R}^{n}, A \in \mathbb{R}^{m x n}$ are mxn type matrixes, and $b \in \mathbb{R}^{m}$ is an m-dimensional unknown vector.

\section{APPLICATION}

In terms of the cost, reject (\%), and service (\%) goals, the selected business desires to determine the amount of raw materials it can supply from each supplier based on its own production capacity and those of the suppliers. The business also aims to increase its competition power by lowering purchase costs without depending on one single supplier.

Table 1 provides information about Cost, Reject Percentage, After-sale Services, and about the supplier companies for an electric engine to be purchased by a company which operates in Agriculture Machinery sector and manufactures grain handling equipments (elevators and conveyors). The company requires a total of 950 electric engines at minimum and 1500 of them at maximum.

Table 1. Supplier Information

\begin{tabular}{|l|l|l|l|l|l|}
\hline & Cost (TL) & Reject(\%) & Service (\%) & $\begin{array}{l}\text { Maximum } \\
\text { Amount }\end{array}$ & $\begin{array}{l}\text { Minimum } \\
\text { Amount }\end{array}$ \\
\hline Supplier 1 & 2535 & 0.3 & 0.89 & 450 & 275 \\
\hline Supplier 2 & 2475 & 0.37 & 0.85 & 375 & 125 \\
\hline Supplier 3 & 2650 & 0.21 & 0.91 & 600 & 450 \\
\hline Supplier 4 & 2325 & 0.46 & 0.82 & 320 & 175 \\
\hline
\end{tabular}

Multiobjective Supplier problem is organized according to Linear Programming model based on the information in Table 1.

$$
\begin{aligned}
& W_{1}: 2535 x_{1}+2475 x_{2}+2650 \mathrm{x}_{3}+2325 \mathrm{x}_{4} \\
& W_{2}: 0.3 \mathrm{x}_{1}+0.37 \mathrm{x}_{2}+0.21 \mathrm{x}_{3}+0.46 \mathrm{x}_{4} \\
& \mathrm{Z}_{1}: 0.89 \mathrm{x}_{1} \mathrm{~W}_{1}+0.85 \mathrm{x}_{2}+0.91 \mathrm{x}_{3}+0.82 \mathrm{x}_{4} \\
& \text { Subject to } \\
& \mathrm{x}_{1}+\mathrm{x}_{2}+\mathrm{x}_{3}+\mathrm{x}_{4} \leq 1500 \\
& \mathrm{x}_{1}+\mathrm{x}_{2}+\mathrm{x}_{3}+\mathrm{x}_{4} \geq 950 \\
& \mathrm{x}_{1} \leq 450 ; \mathrm{x}_{1} \geq 275
\end{aligned}
$$


$\mathrm{x}_{2} \leq 375 ; \mathrm{x}_{2} \geq 125$

$\mathrm{x}_{3} \leq 600 ; \mathrm{x}_{3} \geq 450$

$\mathrm{x}_{4} \leq 320 ; \mathrm{x}_{4} \geq 175$

$\mathrm{x}_{1}, \mathrm{x}_{2}, \mathrm{x}_{3}, \mathrm{x}_{4} \geq 0$ and integer.

In order to model (P1) with Global Criteria Method, the positive ideal solutions were determined first. Decision variable values and positive ideal solutions for each objective function are given in Table 2.

Table 2. Solution for Each Objective Function

\begin{tabular}{|c|c|c|c|}
\hline Decision variables & $\mathbf{W}_{\mathbf{1}}$ & $\boldsymbol{W}_{\mathbf{2}}$ & $\mathbf{Z}_{\mathbf{1}}$ \\
\hline $\mathrm{x}_{\mathbf{1}}$ & 275 & 275 & 450 \\
\hline $\mathrm{x}_{2}$ & 125 & 125 & 275 \\
\hline $\mathrm{x}_{3}$ & 450 & 450 & 600 \\
\hline $\mathrm{x}_{\mathbf{4}}$ & 175 & 175 & 175 \\
\hline $\mathrm{I}^{*}$ & 2605875 & 303.75 & 1323.750 \\
\hline
\end{tabular}

Based on the information in Table 2, Cost and Rejected Percentage objectives are realized at the same values of the same decision variables. On the other hand, Service objective is realized at the different values of the same variable. Therefore, no solution was reached. In order to define all of the three objective functions at the same variable value, (P1) model is written based on (4)

Min G: $\left[\frac{\mathrm{W}_{1}-2605875}{2605875}+\frac{\mathrm{W}_{2}-303.75}{303.75}+\frac{1323.750-\mathrm{Z}_{1}}{1323.750}\right]$

Subject to

$$
\begin{aligned}
& \mathrm{x}_{1}+\mathrm{x}_{2}+\mathrm{x}_{3}+\mathrm{x}_{4} \leq 1500 \\
& \mathrm{x}_{1}+\mathrm{x}_{2}+\mathrm{x}_{3}+\mathrm{x}_{4} \geq 950 \\
& \mathrm{x}_{1} \leq 450 ; \mathrm{x}_{1} \geq 275 \\
& \mathrm{x}_{2} \leq 375 ; \mathrm{x}_{2} \geq 125 \\
& \mathrm{x}_{3} \leq 600 ; \mathrm{x}_{3} \geq 450 \\
& \mathrm{x}_{4} \leq 320 ; \mathrm{x}_{4} \geq 175 \\
& \mathrm{x}_{1}, \mathrm{x}_{2}, \mathrm{x}_{3}, \mathrm{x}_{4} \geq 0 \text { and integer. }
\end{aligned}
$$




\section{N.UMARUSMAN - T.HACIVELIOĞULLARI}

as a Global model. The following is acquired

$$
\operatorname{Min} G:\left[\left(\frac{\mathrm{W}_{1}}{2605875}+\frac{\mathrm{W}_{2}}{303.75}-\frac{\mathrm{Z}_{1}}{1323.750}\right)-1\right]
$$

when the objective function of (P2) is organized. In order to have global objective function as minimum,

$$
\left(\frac{\mathrm{W}_{1}}{2605875}+\frac{\mathrm{W}_{2}}{303.75}-\frac{\mathrm{Z}_{1}}{1323.750}\right)
$$

should be minimized. The Global model reorganized in this regard is given below.

$$
\operatorname{Min}\left(\frac{\mathrm{W}_{1}}{2605875}+\frac{\mathrm{W}_{2}}{303.75}-\frac{\mathrm{Z}_{1}}{1323.750}\right)
$$

Subject to

$$
\begin{aligned}
& \mathrm{x}_{1}+\mathrm{x}_{2}+\mathrm{x}_{3}+\mathrm{x}_{4} \leq 1500 \\
& \mathrm{x}_{1}+\mathrm{x}_{2}+\mathrm{x}_{3}+\mathrm{x}_{4} \geq 950 \\
& \mathrm{x}_{1} \leq 450 ; \mathrm{x}_{1} \geq 275 \\
& \mathrm{x}_{2} \leq 375 ; \mathrm{x}_{2} \geq 125 \\
& \mathrm{x}_{3} \leq 600 ; \mathrm{x}_{3} \geq 450 \\
& \mathrm{x}_{4} \leq 320 ; \mathrm{x}_{4} \geq 175 \\
& \mathrm{x}_{1}, \mathrm{x}_{2}, \mathrm{x}_{3}, \mathrm{x}_{4} \geq 0 \text { and integer. }
\end{aligned}
$$

In order to solve (P3), each objective function will be realized at the same values of the same goal variables. The variable values defined at the solution of (P3) are given in Table 3. 
Table 3. Global Solution

\begin{tabular}{|c|c|c|c|}
\hline Decision Variables & $\mathbf{W}_{\mathbf{1}}$ & $\boldsymbol{W}_{\mathbf{2}}$ & $\mathbf{Z}_{\mathbf{1}}$ \\
\hline $\mathrm{x}_{\mathbf{1}}$ & 275 & 275 & 275 \\
\hline $\mathrm{x}_{2}$ & 125 & 125 & 125 \\
\hline $\mathrm{x}_{3}$ & 450 & 450 & 450 \\
\hline $\mathrm{x}_{4}$ & 175 & 175 & 175 \\
\hline \multicolumn{3}{|c|}{} \\
\hline Objective Function & 2605875 & 303.75 & 904 \\
\hline Distance Degree to the Positive Ideal Solution & 0 & 0 & 0.317092 \\
\hline
\end{tabular}

With the solution of (P3), each objective function is realized at the same value of the same goal variable. Based on these results, positive ideal solution values of Cost and Rejected Percentage objectives in (P1) are the same as the global values of Cost and Reject objectives in (P3). Additionally, the reject status of total products to be purchased is defined as $0,296 \%$, and their service status is defined as $0,881 \%$.

\section{CONCLUSION}

The criteria that companies use in their supplier selection directly effect their preference. Therefore, it is important that supplier selection criteria should be defined as realistic as possible. In this study, the supplier selection criteria were defined as cost, reject percentage, and service success percentage based on the interview with the purchasing department of the company in question. The positive ideal solution values which are acquired with the structured Multiobjective supplier selection problem are provided in Table 2. Based on these results, Cost and Rejected Percentage ratios are realized at the same values of the same decision variables. On the other hand, service success percentage occurs at the different values of the related variables. Therefore, the appropriate solution was not provided by (P1) for all the objectives. Global Criteria Method was used to define the compromise solution which would realize all the goals at the same values of the same variable. Table 3 shows the compromise solution result acquired with the solution (P3) which was organized based on Global Criteria 


\section{N.UMARUSMAN - T.HACIVELIOĞULLARI}

Method. According to these results, Cost and Reject Percentage objectives are more dominant than the Service objective. Because the distance of Cost and Rejected Percentage objectives to their positive ideal solutions are zero. Namely, these two objectives are realized at their positive ideal solutions. On the other hand, the distance of Service Percentage objective to its positive ideal solution is 0.317092 , which means the objective is realized at a value lower than the ideal solution. In this regard, if a significance level is to be determined among the objective functions, the cost and reject objectives have the same significance which is higher than the service percentage objective. Based on the aforementioned knowledge, it is concluded that the business management will select a supplier based on the cost and product return percentage objectives.

In their previous purchases, the business in question has so far acquired products from suppliers only based on their product costs. As the business did not use any methods for purchasing from the suppliers or consider their production capacities, there have been numerous delays in the supply process, which resulted in a negative impact on the business. The quality of the products manufactured by the business and the quality percentage of the after-sale services will increase based on the proposed method and the solution provided by it.

\section{REFERENCES}

AGHAI, S., MOLLAVERDI, N., SABBAGH, M.S. (2014),“A Fuzzy Multi-Objective Programming Model For Supplier Selection with Volume Discount and Risk Criteria”,Int. J. Adv. Manuf. Technol.,71, 1483-1492.

AMID, A., GHODSYPOUR, S.H., O’BRIEN, C.(2006), “Fuzzy Multiobjective Linear Model for Supplier Selection in a Supply Chain”, Int.J. Production Economics, 104, 394-407. 
AMID, A., GHODSYPOUR, S.H., O’BRIEN, C. (2011),”A Weighted Max-Min Model for Fuzzy Multi-Objective Supplier Selection in a Supply Chain”,Int. J. Production Economics, 131, 139-145.

ARIKAN, F. (2013), “A Fuzzy Solution Approach for Multi Objective Supplier Selection”, Expert Systems with Applications, 40, 947-952.

BACHE, J., CARR, R., PARNABY, J., TOBIAS, A.M. (1987), “Supplier Development Systems”, International Journal of Technology Management, 2 (2), 219-228.

BOYCHUK, L., OVCHINNIKOV, V. (1973), ”Principal Methods Of Solution of Multicriterial Optimization Problems", Soviet Automatic Control, 6,1-4.

CHEN, K.L., CHEN, K.S., LI, R.K. (2005), "Suppliers Capability and Price Analysis Chart”, International Journal of Production Economics, 98, 315-327.

CHOUDHARY, D., SHANKAR, R. (2014), “A Goal Programming Model For Joint Decision Making of Inventory Lot-Size, Supplier Selection and Carrier Selection”, Computers \& Industrial Engineering, 71, 1-9.

DEMPSEY, W. A. (1978), "Vendor Selection and the Buying Process”,Industrial Marketing Management, 7, 257-267.

DICKSON, G.W. (1966), “An Analysis of Vendor Selection Systems and Decisions”,Journal of Purchasing, 2 (1), 5-17.

DING, H., BENYOUCEF, L., XIE X. (2003),“A SimulationOptimization Approach Using Genetic Search for Supplier Selection”, Proceedings of the 2003 Winter Simulation Conference, New Orleans, USA, 1260-1267.

GABALLA, A.A. (1974), "Minimum Cost Allocation of Tenders”, Operational Research Quarterly, 25 (3), 389-398.

GHODSYPOUR, S.H., O’BRIEN, C. (1996), “A Decision Support System for Supplier Selection Using an Integrated Analytic Hierarchy Process and Linear Programming”,Int. J. Production Economics, 56-57, 199-212. 


\section{N.UMARUSMAN - T.HACIVELİOĞULLARI}

GOVINDAN, K., DARBARI, J.D., AGARWAL, V., JHA, P.C. (2017), "Fuzzy Multi-Objective Approach For Optimal Selection of Suppliers and Transportation Decisions in an Eco-Efficient Closed Loop Supply Chain Network”,Journal of Cleaner Production, 165, 1598-1619.

HO, W., XU, X. AND PRASANTA DEY K. (2010), "Multi-Criteria Decision Making Approaches For Supplier Evaluation and Selection: A Literature Review”,European Journal of Operational Research, 202, 16-24.

HWANG, C. L., MASUD, A. S. (1979),Multiple Objective Decision Making-Methods andApplications: A State-of-The-Art Survey, SpringerVerlag, Berlin.

JADIDI, O., CAVALIERI, S., ZOLFAGHARI, S. (2015), “An improved multi-choice goal programming approach for supplier selection problems”,Applied Mathematical Modelling, 39, 4213-4222.

KILINÇCI, Ö AND ÖNAL, S.A. (2011), "Fuzzy AHP Approach for Supplier Selection in a Washing Machine Company”, Expert Systems with Applications, 38, 9656-9664.

KUMAR, M., VRAT, P., SHANKA, R. (2004), “A Fuzzy Goal Programming Approach For Vendor Selection”.Computers \& Industrial Engineering, 46, 69-85.
LAI
Y-J.,
HWANG,
C-L.,(1994),

FuzzyMultipleObjectiveDecisionMaking: MethodsandApplications (LectureNotes in Economicsand Mathematical Systems), Springer-Verlag, Berlin.

LEE, .H.I., KANG, H.Y., CHANG, C.T. (2009), “Fuzzy Multiple Goal Programming Applied to TFT-LCD Supplier Selection by Downstream Manufacturers”,Expert Systems with Applications, 36, 6318-6325.

LEE, S.H. (2017), “A Fuzzy Multi-Objective Programming Approach For Determination of Resilient Supply Portfolio Under Supply Failure Risks”, Journal of Purchasing \& Supply Management, 23, 211-220.

MIZRAK ÖZFIRAT, P., ÖĞÜT, C. (2008),“An Applicatıon of Analytic Hierarchy Process and Goal Programming in Supplier Selection Problem”,DEÜ MühendislikFakültesi Fen veMühendislikDergisi, 10 (1), 39-48. 
POWER, M.J., DESOUZA, K.C., BONIFAZI, P. (2006), The Outsourcing Handbook: How to Implement a Successful Outsourcing Process, Kogan Page Limited UK.

ROA, C.P., KISER, G.E. (1980), "Educational Buyers Perceptions of Vendor Attributes”,Journal of Purchasing and Materials Management, 16, 25-30.

SALUKVADZE, M. (1974), "On The Existence Of Solution in Problems of Optimization Under Vector Valued Criteria”, Journal of Optimization Theory and Applications,12(2),203-217.

SHAW, K., SHANKA, R., SURENDRA YADAV, S., THAKUR LAKSMAN, S. (2012), "Supplier Selection Using Fuzzy Ahp and Fuzzy Multi-Objective Linear Programming for Developing Low Carbon Supply Chain”, Expert Systems with Applications 39, 8182-8192.

SAWIK, T. (2010), "Single Vs. Multiple Objective Supplier Selection In A Make To Order Environment”,Omega, 38, 203-212.

SHIRKOUHI, S.N., SHAKOURI, H., JAVADI, B., KERAMATI, A. (2013). "Supplier Selection And Order Allocation Problem Using A TwoPhase Fuzzy Multi-Objective Linear Programming”,Applied Mathematical Modelling, 37, 9308-9323.

Umarusman, N., Türkmen, A. (2013), "Building Optimum Production Settings Using De Novo Programming with Global Criterion Method", International Journal of Computer Applications, Volume 82, No 18,12-15.

WEBER, C. A., CURRENT, J. R., BENTON, W. C. (1991), "Vendor Selection Criteria and Methods",European Journal of Operational Research, 50, 2-18.

WEBER, C.A., CURRENT, J.R. (1993), “Theory and Methodology: A Multi-Objective Approach to Vendor Selection”,European Journal of Operational Research, 68, 173-184.

WU, D.D., ZHANG, Y., WU, D., OLSON, D.L. (2010), "Fuzzy MultiObjective Programming For Supplier Selection And Risk Modelling: A Possibility Approach”,European Journal of Operational Research,200, 774787. 


\section{N.UMARUSMAN - T.HACIVELİOĞULLARI}

ZELENY, M. (1982), Multiple Criteria Decision Making, Mc Graw-Hill Book COMPANY, NEW YORK.

ZIMMERMANN, H.J. (1978) Fuzzy programming and linear programming with several functions, Fuzzy Sets and Systems,1, 45-55. 